\title{
Using of Essential Oil Mixture in Quail Breeders (Coturnix Coturnix Japonica) for Improving Cecal Short-Chain Fatty Acid Concentrations
}

\author{
Özlem Durna Aydın ${ }^{1, a, *}$, Gültekin Yıldız ${ }^{2, b}$ \\ ${ }^{1}$ Department of Animal Nutrition, Nutritional Diseases, Veterinary Faculty, Kafkas University, 36040 Kars, Turkey \\ ${ }^{2}$ Department of Animal Nutrition, Nutritional Diseases, Veterinary Faculty, Ankara University, 06830 Ankara, Turkey
}

*Corresponding author

\section{A R T I C L E I N F O A B S T R A C T}

Research Article

The aim of this study is to investigate the effect of added to mixture essential oil consist of mint oil, juniper oil, rosemary oil and oregano vulgare oil added in drinking water at on intestinal health in quail breeders. A total of 160 Japanese quail breeders (control group each subgroup 6 females 6 males, experimental groups each subgroup 5 females 5 males) 17 weeks of age were randomly

Received : 13/07/2020

Accepted : 04/09/2020 divided into 3 treatment groups and each group was divided into 5 replicates. The experimental period lasted 56 days. Maize and soybean meal-based diets were offered ad libitium to the birds from during the experimental period. Treatments were as follows: C, (Control; without supplementation to the drinking water); E1 $(0,1 \mathrm{ml} / \mathrm{L}$ essential oil mixture supplementation to the drinking water) and $\mathrm{E} 2(0,3 \mathrm{ml} / \mathrm{L}$ essential oil mixture supplementation to the drinking water. Acetic acid, butyric acid, isocaproic acid and SCFA values were linearly affected by the increasing level of essential oil mixture (mint oil, juniper oil, rosemary oil and oregano vulgare oil). There were no significant differences in propionic acid, isobutyric acid, valeric acid, isovaleric acid, caproic acid and BCFA concentrations. In conclusion, essential oil mixture consists of mint oil, juniper oil, rosemary oil and oregano vulgare oil can be used to improve intestinal health in quail breeders drinking water.

Japanese quail breeders

Coturnix coturnix japonica Extract

Cecum short-chain fatty acid Intestinal health

\section{Introduction}

The prolonged use of antibiotics as growth factor in poultry has prevented the growth of pathogenic microorganisms in the digestive tract of animals as well as beneficial microorganisms (Kahraman et al., 1996). Use of antibiotics in feeds has promoted development of antibiotic resistance of bacteria. In addition, residues in animal products have become a risk to human health (Aarstrup et al., 2000). For these negative reasons, the use of antibiotics as a growth promoter in animal feed have been prohibited. After that probiotics, prebiotics, enzymes, organic acids and other products, such as essential oils, started to be used as an alternative feed additive to antibiotics (Wiseman, 2012).

Rosemary (Rosmarinus officinalis L.) is an aromatic plant with strong antioxidant activitiy in the Lamiaceae family (Carvalho et al., 2005). The leaves of it contain strong antioxidants such as carnosol, rosmarinic acid and carnosic acid. Carnosic acid is known to be the most powerful antioxidant for animal fats. Mint (Mentha L.), is a member of the Labiatae family. As active compounds of the peppermint plant, flavones, rosmaniric acid, caffeic, chlorogenic acid and triterpenic substances (Öztürk et al., 2002). Juniper (Juniperus spp) is a plant belonging to the Cupressaceae family (Mataraci, 2004). Juniper in the composition of fruits; inositis, flavonoids, glycosides, bitter compounds (juniperin), resin, invert sugar, katesin, organic acids, volatile oil, terpenic acids, lacoanthocyanidine substances have been reported (Koç, 2002). Oregano is a common term for the plant family Lamiaceae (Olivier, 1997). Oregano is rich in carvacrol and at a lesser extent in phenolic monoterpenoids (particularly thymol) (D'antuono et al., 2000). Obtained as a result of the studies according to the information of these plant extracts appetite enhancer, digestive stimulant, anticoccidial, antihelmintic, antiviral, antimicrobial and antioxidant properties (Jamroz and Kamel, 2002). 
In recent years, many studies were conducted with focused on the aromatic plants and their extracts. However, there is no study, in which the relationship between the oil mixture added to the drinking water. However, there was too limited few studies investigating the effect of essential oil mixture on cecum SCFA in breeder quail. In this study, our aim is to search the effect of essential oil mixture added to the drinking water on intestinal health of breeder quail.

Table 1. Composition of basal diet used in the experiment (\%)

\begin{tabular}{l|r}
\hline \multicolumn{1}{c|}{ Ingredients } & $\%$ \\
\hline Corn & 61.50 \\
Soyben meal & 27.25 \\
Corn gluten $(\mathrm{CP} \%, 60)$ & 1.00 \\
Marble powder & 7.50 \\
DCP & 1.75 \\
DL- methionine & 0.13 \\
L-lysine Hydrochloride & 0.17 \\
Vit- min premix & 0.35 \\
Salt & 0.35 \\
\hline \multicolumn{2}{c}{ The formulated value } \\
\hline \multicolumn{2}{c}{ Analysis Values: } \\
\hline Crude protein, \% & 100.00 \\
ME (kcal/kg) & 17.51 \\
Ca, \% & 3.20 \\
\hline Total P, \% & 0.60 \\
\hline *ME (kcal/kg) & 2715 \\
Crude protein, \% & 17.39 \\
\hline
\end{tabular}

Composition (per 2.5kg): $3.6 \mathrm{~g}$ retinol, $0.12 \mathrm{~g}$ cholecalciferol, 30g DL-0 tocopherol acetate, $2 \mathrm{~g}$ menadione, $2.5 \mathrm{~g}$ thiamine, $6 \mathrm{~g}$ riboflavin, $4 \mathrm{~g}$ pyridoxine, $20 \mathrm{mg}$ cobalamin, $25 \mathrm{~g}$ niacin, $8 \mathrm{~g}$ calcium-D-panthotenate, $1 \mathrm{~g}$ folic acid, $50 \mathrm{~g}$ ascorbic acid, $50 \mathrm{mg}$ D-biotin, $15 \mathrm{~g}$ choline chloride, $1.5 \mathrm{~g}$ canthaxanthin, $0.5 \mathrm{~g}$ apo carotenoic acid esters, $80 \mathrm{~g} \mathrm{Mn}, 60 \mathrm{~g} \mathrm{Zn}, 60 \mathrm{~g} \mathrm{Fe}$, $5 \mathrm{~g} \mathrm{Cu}, 1 \mathrm{~g} \mathrm{I}, 0.5 \mathrm{~g} \mathrm{Co}, 0.15 \mathrm{~g} \mathrm{Se}$.

Table 2: Chemical composition essential oil mix used in experiment $(\%)$

\begin{tabular}{l|c}
\hline \multicolumn{1}{c|}{ Product Compotision* } & $\%$ \\
\hline Mint oil & 2 \\
Juniper Oil & 2 \\
Rosemory Oil & 2 \\
Oregano Vulgare oil & 2 \\
Surfactants and Stabilizers & 15 \\
Water (transporter) & 77 \\
\hline
\end{tabular}

*Mintofarm

\section{Materials and Methods}

\section{Animals, Experimental Design and Feed}

The study was carried out with the permission of the Kafkas University Animal Experiments Local Ethics Committee (Decision No: KAU-HAYDEK /2019-106) report. A total of 160 Japanese quail breeders (control group each subgroup 6 females 6 males, experimental groups each subgroup 5 females 5 males) aged 17 weeks were randomly divided into 3 groups and each group were divided into 5 replicates. Maize and soybean meal-based diets were offered to the birds during the experimental period (Table 1). Feed and water are given as ad libitium. The diet was formulated to meet or exceed NRC (1994) nutrient recommendations. Nutrient analysis of diet was performed according to AOAC (2000). Each experimental group was reared identically $\left(22^{\circ} \mathrm{C}, 60-70 \% \mathrm{RH}, 16 \mathrm{~h}\right.$ light and ad libitum water and feed) for a period of 56 days. Treatments were as follows: C, (Control; without essential oil mixture supplementation to the drinking water); E1 (0,1 $\mathrm{ml} / \mathrm{L}$ essential oil mixture supplementation to the drinking water) and E2 $(0.3 \mathrm{ml} / \mathrm{L}$ essential oil mixture supplementation to the drinking water). Essential oil mixture (Mintofarm) used in the research from a private company (FARMAVET A.Ş.). Mintofarm consist of mint oil, juniper oil, rosemary oil and oregano vulgare oil. Certified analysis used in the research and reported by the manufacturer according to the results of the chemical composition of the product. The results were given in Table 2 .

\section{Cecal short-chain fatty acid concentrations}

The cecal digesta that were obtained after sacrificed with the animals was used for the determination of acetic, propionic, butyric, isobutyric, valeric and caproic acid with a gas chromatography (Shimadzu GC, Shimadzu Co., Kyoto, Japan), a flame ionization detector (FID) and colons (Teknokroma; TR-151035, TRB-FFAP $30 \mathrm{~m} \times 0.53$ $\mathrm{mm} \times 0.50 \mu \mathrm{m})$. At the end of the study, the cecum content was stored at $-18^{\circ} \mathrm{C}$ and then were dissolved at $+4^{\circ} \mathrm{C}$ before analysis. The contents were centrifuged at $4000 \mathrm{rpm}$ for $15 \mathrm{~min}$ at $+4^{\circ} \mathrm{C}$ for homogenization. The supernatant was taken into an Eppendorf tube and mixed with $0.2 \mathrm{~mL}$ ice-cold $25 \%$ metaphosphoric acid solution. After that, the tubes were kept in ice for 30 min to ensure the collapse of proteins. Subsequently, tubes were centrifuged for $10 \mathrm{~min}$ at $11000 \mathrm{rpm}$ at $+4^{\circ} \mathrm{C}$. Supernatants were analysed using GC. The analysis was performed according to Zhang et al. (2003). Helium was used for the carrier gas and the colon temperature was programmed so that it was increased stepwise from $110^{\circ} \mathrm{C}$ to $180^{\circ} \mathrm{C}$. Also, the FID and injector block temperature was set to $250^{\circ} \mathrm{C}$.

\section{Statistics Analysis}

The one-way analysis of varience (ANOVA) method was used for the statistical calculations of the groups and polynomial contrast test was used to determine the effect of the probiotic used at different levels in the groups (SPSS, 2011).

\section{Results}

Cecal short-chain fatty acids $(\mu \mathrm{mol} / \mathrm{g})$ concentrations of the birds are given in Table 3 . Asetic acid $(\mathrm{P}=0.026)$, butyric acid $(\mathrm{P}=0.021)$, isocaproic acid $(\mathrm{P}=0.000)$ and total SCFA ( $\mathrm{P}=0.002)$ were linearly affected by the increasing level of essential oil mixture (mint oil, juniper oil, rosemary oil and oregano vulgare oil) $(\mathrm{P}=0.026, \mathrm{P}=0.021$, $\mathrm{P}=0.000$ and $\mathrm{P}=0.002$, respectively). There were no significant differences in propionic acid, isobutyric acid, valeric acid, isovaleric acid, caproic acid and BCFA concentrations.

\section{Discussion}

Short chain fatty acids are formed by bacterial fermentation. Short-chain fatty acids stimulate cell growth and differentiation in the gut, thereby improving intestinal integrity, as well as preventing the growth of pathogenic microorganisms by lowering the digestive system $\mathrm{pH}$ (Knudsen et al., 2012). Poultry meets 5-10\% of their 
energy need from volatile fatty acids formed by fermentation in cecum (Gasaway, 1976). Weng et al. (2019) reported that in the study of correlation of variables on metabolic and microbiota with diet in case of intestinal inflammation, the value of isocaproic acid decreased. Decrease in isocaproic acid value; it shows that the $\mathrm{pH}$ acidity in the intestine is impaired and pathogenic microorganisms are active in the inflammation area. In the light of these studies, the increase in secum short chain fatty acids can be interpreted as having a positive effect on intestinal health. Among SCFAs, butyric acid is a primary energy source for enterocytes. In cellular differentiation and takes part in proliferation in the intestinal mucosa (Rinttila and Apajalahti, 2013). In our study, acetic acid, butyric acid, isocaproic acid and SCFA were linearly affected by the increasing level of essential oil mixture. There were no significant differences in propionic acid, isobutyric acid, valeric acid, isovaleric acid, caproic acid and BCFA concentrations. The number of studies investigating cecum SCFA in intestinal health in poultry is very limited. Moreover, in the literature search, no articles investigating quail on SCFAs were found. In one study, the addition of bilberry to rat diets enriched cecum SCFAs (Liu et al., 2019). The presence of green tea extract and black tea extract in rat rations stimulated cecum SCFA production (Unno and Osakabe, 2018). On the other hand, use of thyme and black cumin oil in broiler rations did not affect cecum SCFA (Durna Aydin and Y1ld1z, 2020). The conflicting results of these studies might depend on the factors related to the herbs such as the type and dose of the added plant extracts, the ratio of the volatile fatty acids and active ingredients, interactions and on the composition of the ration, coop conditions, and environmental factors.

Table 3. Effect of essential oil mixture on cecal short-chain fatty acid concentrations at the end of the experiment $(\mu \mathrm{mol} / \mathrm{g})$.

\begin{tabular}{l|cccccc}
\hline \multirow{2}{*}{\multicolumn{1}{c|}{ SCFA Parameters }} & \multicolumn{4}{c}{ Groups } \\
\cline { 2 - 7 } & \multirow{2}{*}{$\mathrm{C}(\overline{\mathrm{x}})$} & $\mathrm{E} 1(\overline{\mathrm{x}})$ & E2 $(\overline{\mathrm{x}})$ & SEM & \multicolumn{2}{c}{ Significance } \\
\hline Acetic acid & 31.15 & 51.26 & 51.06 & 3.88 & 0.026 & 0.159 \\
Propionic acid & 14.72 & 19.63 & 20.09 & 2.05 & 0.319 & 0.627 \\
Isobutyric acid & 0.41 & 0.53 & 0.48 & 0.03 & 0.443 & 0.233 \\
Butyric acid & 7.65 & 7.78 & 14.91 & 1.37 & 0.021 & 0.165 \\
Isovaleric acid & 0.82 & 1.05 & 1.02 & 0.12 & 0.567 & 0.656 \\
Valeric acid & 0.18 & 0.18 & 0.17 & 0.02 & 0.892 & 0.928 \\
Isocaproic acid & 0.93 & 1.68 & 2.27 & 0.17 & 0.000 & 0.742 \\
Caproic acid & 1.98 & 2.10 & 1.97 & 0.05 & 0.977 & 0.300 \\
BCFA & 3.22 & 3.70 & 3.48 & 0.13 & 0443 & 0.227 \\
\hline Total SCFA & 56.76 & 82.39 & 89.54 & 4.92 & 0.002 & 0.230 \\
\hline
\end{tabular}

${ }^{1}$ Data represent mean values of 5 replicates per treatment, ${ }^{2}$ Groups; $\mathrm{C}$ : Control without supplementation drinking water, E1: $0.1 \mathrm{~mL}$ mixture oils added to drinking water and E2: $0.3 \mathrm{~mL}$ mixture oils added to drinking water, ${ }^{3}$ Polynomial contrasts: $\mathrm{L}=$ linear and $\mathrm{Q}=\mathrm{quadratic}$ effect of supplemental mixture oils. ${ }^{4}$ BCFA (Branched Chain Fatty Acids): isobutyric acid+isovaleric acid+valeric acid. ${ }^{5}$ Total SCFA (Short Chain Fatty Acids): acetic acid+propionic acid+isobutyric acid + butyric acid+isovaleric acid+valeric acid.

\section{Conclusion}

The addition of essential oil mixture to the drinking water of quail breeders may improve intestinal health by affecting cecum short chain fatty acid composition. Further studies are needed to illuminate the investigated parameters.

\section{Conflict of Interest}

The authors declare that there is no conflict of interest.

\section{Acknowledgments}

We would like to thank Mechanical Engineer Taner Aydin for his support on grammar correction.

\section{References}

Aarestrup FM, Kruse H, Tast E, Hammerum AM, Jensen LB. 2000. Associations between the use of antimicrobial agents for growth promotion and the occurrence of resistance among Enterococcus faecium from broilers and pigs in Denmark, Finland, and Norway. Microb. Drug. Resist. 6 (1): 63-70. doi: $10.1089 / \mathrm{mdr} .2000 .6 .63$

AOAC. 2000. Official methods of analysis of the association of official analytical chemists. seventeenth ed. AOAC International, Maryland, USA.
Carvalho RN, Moura LS, Rosa PTV, Meireles MAA. 2005.Supercritical fluid extraction from rosemary (Rosmarinus officinalis): Kinetic data, extract's global yield, composition and antioxidant activity. J. Supercrit Fluids, 35:197-204.

D'antuono LF, Galleti GC, Bocchini P. 2000. Variability of essential oil content and composition of origanum vulgare I. populations from a north mediterranean area (Liguria Region, Northern Italy). Annals of Botany. 86: 471- 478.

Durna Aydin O, Yildiz G. 2020. The effects of thyme oil and black cumin oil in broiler feeding on growth performance, intestinal histomorphology, and cecal volatile fatty acids. Turk J Vet Anim. Sci, 44: 17-25. doi:10.3906/vet-1907118

Gasaway WC. 1976. Volatile fatty acids and metabolizable energy derived from cecal fermentation in the willow ptarmigan. Comp Biochem Physiol, 53A, 115.

Jamroz D, Kamel C. 2002. Plant extacts enhance broiler performance. In non-ruminant nutrition: Antimicrobial agents and plant extracts on immunity, health and performance. J Anim. Sci. 80:41.

Kahraman R, Alp M, Kocabağlı N, Irmak G, Şenel HS. 1996. The effects of fastrack and sodium bicarbonate on performance of broilers. Turk J Vet Anim. Sci, 20: 383 386.

Knudsen KEB, Hedemann MS, Lærke HN. 2012. The role of carbohydrates in intestinal health of pigs. Anim. Feed Sci Technol, 173: 41-53. 
Koç H. 2002. Lokman Hekimden Günümüzde Bitkilerle Sağlıklı Yaşama. T.C. Kültür Bakanlığı Yayınları No: 2883, Yayımlar Dairesi Başkanlığ 1 Kültür Eserleri Dizisi No: 373-431. ISBN: 975- 17-2925-4. Başbakanlık Basımevi, Ankara.

Liu HY, Walden TB, Cai D, Ahl D, Bertisson S, Philipson M, Nyman M, Holm L. 2019. Dietary fiber in bilberry ameliorates preobesity events in rats by regulating lipid depot, cecal short-chain fatty acid formation and microbiota composition. Nutrients.11(6): 1350. doi: 10.3390/nu11061350

Mataraci T. 2004. Ağaçlar, doğa severler için rehber kitap. Tema Vakfi Yayın No: 39, ISBN: 975-7169-46-3. Tema Vakf Yayınları, İstanbul.

NRC. 1994. Nutrient requirements of poultry. nineth rev. ed. National Academy Press, Washington DC, 34-45.

Olivier GW. 1997. The world market of oregano. In: Padulosi S, (ed.) Oregano, 14. Proceedings of the IPGRI International Workshop. Rome, Italy, 142-146.

Öztürk B, Konyalığlu S, Baykan LS. 2002. Türkiye'de doğal yayılış gösteren bazı Thymus $L$. taksonlarının uçucu yağlarının karșılaștırmalı antioksidan etkileri. 14. İlaç Hammaddeleri Toplantısı Bildiriler.
Rinttil"a, T, Apajalahti, J. 2013. Intestinal microbiota and metabolites Implications for broiler chicken health and performance. J Appl Poult Res, 22: 647-658.

SPSS. 2011. Statistical Packages for the Social Sciences, twentieth. ed. IBM Inc, Chicago, USA.

Unno T, Osakabe N. 2018. Green tea extract and black tea extract differentially influence cecal levels of short chain fatty acids in rats Food Sci Nutr, 6: 728-735. doi: 10.1002/fsn3.607

Weng YJ, Gan HY, Li X, Huang Y, Li ZC, Deng HM, Chen SZ, Zhou Y, Wang LS, Han YP, Tan YF, Song YJ, Du ZM, Liu YY, Wang Y, Qin N, Bai Y, Yang RF, Bi YJ, Zhi FC. 2019. Correlation of diet, mic-rob iota and metabolite networks in inflammatory bowel disease. J Dig Dis 20:447-459. doi: 10.1111/1751-2980.12795

Wiseman M. 2012. Evaluation of Tasco as a candidate prebiotic in broiler chickens. Dalhousie University.

Zhang WF, Li DF, Lu WQ, Yi GF. 2003. Effects of isomaltooligosaccharides on broiler performance and intestinal microflora. Poul. Sci, 82(4): 657-663. 